\title{
IDENTIFIKASI PERSONAL DAN IDENTIFIKASI KORBAN BENCANA MASSAL DI BLU RSUP PROF DR R.D KANDOU MANADO PERIODE JANUARI 2010 - DESEMBER 2012
}

\author{
${ }^{1}$ Gladys L. Monica \\ ${ }^{2}$ James F. Siwu \\ ${ }^{2}$ Johannis F. Mallo
}

\author{
${ }^{1}$ Kandidat Skripsi Fakultas Kedokteran Universitas Sam Ratulangi Manado \\ ${ }^{2}$ Bagian Ilmu Kedokteran Forensik dan Medikolegal Fakultas Kedokteran \\ Universitas Sam Ratulangi Manado \\ Email: gladyslydiamonica@yahoo.com
}

\begin{abstract}
In forensic identification, the identity is determined by comparing two sets of data, antemortem and postmortem. This identification is important to the victims' families because that is the embodiment of human rights and reverence to the deceased body. This study aimed to obtain data regarding the management of personal and disaster victims' identification in Prof. Dr. R.D Kandou Hospital Manado from January 2010 through December 2012. This was a retrospective study with a cross sectional design. Data were obtained from the Forensic Medicine Department in Prof. Dr. R.D Kandou Hospital, Manado. Samples were dead bodies without any identities. The results showed that during 2010-2012 there were 20 dead bodies without identities out of the total 7,296, consisting of 3 fresh dead bodies, 4 fetus suspected due to abortion, 3 dead bodies in skeleton forms, and 10 disaster victims (a heli crash). Nondisaster victims were identified by using visual, documentary, personal property, and medical examination methods, meanwhile disaster victims were identified by using the standard procedure for disaster victim identification (DVI) from interpol. Conclusion: The implementation of identification in Prof. Dr. R.D. Kandou Hospital from January 2010 through December 2012 used visual, documentary, personal property, and medical examination methods. Moreover, identification of disaster victims were carried out by using the DVI from interpol. The descriptions were stated in the deduction reports which contained morgue data, autopsy examinations, and conclusions.
\end{abstract}

Keywords: identification, dead victims, disaster, DVI.

\begin{abstract}
Abstrak: Identifikasi forensik penting dilakukan terhadap korban meninggal karena merupakan perwujudan HAM dan penghormatan terhadap yang telah meninggal. Penelitian ini bertujuan untuk memperoleh informasi tentang pelaksanaan identifikasi personal dan korban bencana massal di BLU RSUP Prof. DR. R.D. Kandou Manado pada periode tahun 2010-2012. Penelitian ini menggunakan metode retrospektif dengan cross sectional design. Data yang digunakan ialah data sekunder berupa laporan yang diperoleh dari Bagian Ilmu Kedokteran Forensik dan Medikolegal BLU RSUP Prof Dr. R.D. Kandou Manado. Sebagai sampel yaitu data jenazah tanpa identitas dan diperoleh sebanyak 20 sampel yang terdiri dari 3 jenazah segar, 4 janin yang diduga merupakan korban aborsi, 3 jenazah dalam bentuk kerangka, dan 10 jenazah akibat kecelakaan lintas udara (heli crash) di Bitung. Identifikasi dilakukan dengan menggunakan metode visual, dokumen, properti, dan medik. Untuk korban kecelakaan lintas udara, identifikasi dilakukan dengan menggunakan prosedur standar Interpol yaitu Disaster Victim Identification (DVI). Simpulan: Pelaksanaan identifikasi di BLU RSUP Prof DR R.D Kandou Manado periode Januari 2010-Desember 2012 menggunakan metode visual, dokumen, properti, dan medik, sedangkan untuk
\end{abstract}


identifikasi korban bencana massal digunakan DVI. Uraian mengenai metode tersebut tersirat dalam laporan deduksi yang memuat data jenazah, hasil pemeriksaan fisik (luar dan dalam), serta simpulan.

Kata kunci: identifikasi, jenazah, Bencana, DVI.

Jumlah mayat tanpa identitas sepanjang tahun 2010 meningkat dibandingkan tahun sebelumnya. Di Rumah Sakit Kepolisian Pusat R.S. Sukanto, jumlah tersebut meningkat sekitar $50 \%$. Sebagian mayat berasal dari gelandangan, dan lainnya merupakan korban kejahatan pembunuhan maupun bayi yang ditelantarkan orang tuanya. ${ }^{1}$ Pada tahun 2012 , kamar jenazah RSUD Cianjur menerima 1.191 mayat dalam lima bulan terakhir; 13 diantaranya ialah mayat tidak dikenal. Diperkirakan terdapat 20 jenazah tidak dikenal yang diterima setiap tahunnya. ${ }^{2}$ Angka kejadian bencana di Indonesia mengalami peningkatan dan menimbulkan korban jiwa serta kerugian yang besar. ${ }^{3}$ Keadaan ini dapat terlihat laporan berbagai media massa yang memuat berita mengenai kejadian bencana, kecelakaan transportasi, aksi teror bom, gempa bumi, tsunami, banjir, tanah longsor, letusan gunung berapi, puting beliung, dan lain-lain. ${ }^{4}$ Badan Nasional Penanggulangan Bencana (BNPB) merilis jumlah bencana alam yang terjadi di Indonesia sepanjang tahun 2012 yaitu mencapai angka 1.598 yang sangat meningkat dibandingkan tahun 2010 yang hanya mencapai angka 644 . $^{3,5}$

Identifikasi forensik merupakan upaya yang dilakukan dengan tujuan membantu penyidik untuk menentukan identitas seseorang. ${ }^{6-8}$ Penentuan identitas korban seperti halnya penentuan identitas tersangka pelaku kejahatan merupakan bagian terpenting dalam penyidikan. ${ }^{7,9}$ Identifikasi tersebut penting sekali dilakukan terhadap korban meninggal karena merupakan perwujudan HAM dan penghormatan terhadap orang yang sudah meninggal. ${ }^{10}$ Kitab Undang-Undang Hukum Acara Pidana (KUHAP) Pasal 133 ayat tiga tertulis "Mayat yang dikirim kepada ahli kedokteran kehakiman atau dokter pada rumah sakit harus diperlakukan secara baik dengan penuh penghormatan terhadap mayat tersebut dan diberi label yang memuat identitas mayat, dilak dengan diberi cap jabatan yang dilekatkan pada ibu jari kaki atau bagian lain badan mayat ". ${ }^{11}$ Dengan demikian, dapat dipahami bahwa proses identifikasi merupakan hal yang penting untuk dilaksanakan sebelum proses selanjutnya yaitu pemeriksaan mayat (otopsi). ${ }^{12,13}$

Identifikasi dapat dilakukan dalam tiga cara: visual (kerabat atau kenalan melihat jenazah); data secara rinci (misalnya, data ante-mortem yang cocok dengan informasi yang dikumpulkan selama autopsy dan informasi situasional lainnya); dan secara ilmiah atau objektif (misalnya, pemeriksaan gigi, sidik jari, atau DNA). Identifikasi tidak mutlak berdasarkan urutan diatas; jika perlangsungan proses identifikasi menjadi lebih sulit, cara selanjutnya yang dilakukan. Bila memungkinkan, identifikasi visual harus dilengkapi dengan salah satu dari dua metode lain. ${ }^{14}$

Pada dasarnya, identifikasi terdiri dari dua metode utama, yaitu: 1) identifikasi komparatif, yaitu bila selain data post mortem juga tersedia data ante mortem, dalam suatu komunitas yang terbatas, dan 2) identifikasi rekonstruktif, yaitu bila tidak tersedia data ante mortem dan komunitas tidak terbatas. ${ }^{12}$ Penentuan identitas personal dapat menggunakan metode identifikasi visual, doukumen, properti, pemeriksaan medik, gigi, serologik, sidik jari, analisis DNA, dan secara eksklusi. Identitas seseorang dapat dipastikan bila paling sedikit dua metode yang digunakan memberikan hasil positif (tidak meragukan). ${ }^{6,15}$ Prosedur identifikasi pada korban bencana massal mengacu pada prosedur Disaster Victim Identification (DVI) yang dikeluarkan oleh Interpol. Proses DVI yang terdiri dari lima fase, yaitu: the scene, post mortem examination, ante mortem information 
retrieval, reconciliation, dan debriefing. ${ }^{4,15,16}$

Proses identifikasi tidak jarang diperhadapkan dengan berbagai kendala sehingga dapat memperlambat penyidikan identitas dari jenazah tersebut. ${ }^{17}$ Terdapatnya kendala dalam proses identifikasi, antara lain karena tidak konsistennya pengumpulan data ante mortem (misalanya pendataan gigi) sehingga identifikasi jenazah tersebut menjadi sulit dan membutuhkan waktu lama untuk dikonfirmasi walaupun sudah mendapatkan pengelolaan professional yang baik dalam proses identifikasi. $^{18,19}$ Proses identifikasi pada korban bencana massal juga mengalami banyak hambatan di penyidikan lapangan dalam menerapkan prosedur DVI. ${ }^{4}$

Masyarakat Indonesia memiliki keterbatasan dalam data ante mortem. Tidak lebih dari $10 \%$ penduduk Indonesia yang diketahui sidik jarinya, dan hal inipun tidak mudah diakses. Golongan darah yang diketahui biasanya hanya golongan $\mathrm{ABO}$ yang memiliki nilai eksklusi rendah. Di Indonesia hampir tidak ditemukan data gigi yang baik kecuali pada kelompok masyarakat tertentu seperti penerbang dan TNI, namun data giginya juga tidak mengikuti ketentuan internasional (Interpol). ${ }^{12}$ Berdasarkan penelitian Smith dan Hanzlick ${ }^{20}$ pada 100 jenazah tanpa identitas, metode yang paling menunjang identifikasi ialah visual (52\%), sidik jari (31\%), gigi (10\%), sinar-X $(4 \%)$, dan metode lainnya $(6 \%){ }^{20}$ Penelitian Cavard et al. ${ }^{21}$ memperoleh hasil yang berbeda yaitu dari 134 kasus diperoleh bahwa hampir $28 \%$ telah diidentifikasi dengan biologi molekuler (DNA), 23\% dengan pemeriksaan odontologi, 7,5\% dengan sidik jari, dan $6,7 \%$ dengan data otopsi.

\section{METODE PENELITIAN}

Penelitian ini menggunakan metode retrospektif dengan cross sectional design. Data yang digunakan ialah data sekunder berupa laporan yang diperoleh dari Bagian Ilmu Kedokteran Forensik dan Medikolegal BLU RSUP Prof. Dr. R.D Kandou Manado. Sampel yang diambil yaitu data jenazah tanpa identitas yang diterima selama kurun waktu tahun 2010-2012. Kriteria inklusi dalam penelitian ini ialah jenazah tanpa identitas.

\section{HASIL PENELITIAN DAN BAHASAN}

Tabel 1 dan Gambar 1 memperlihatkan jumlah jenazah yang diterima di Bagian Ilmu Kedokteran Forensik dan Medikolegal BLU RSUP Prof. Dr. R.D Kandou Manado selama tahun 2012, 2011, dan 2012. Berdasarkan kriteria inklusi didapatkan sampel sebanyak 20 jenazah tanpa identitas dalam kurun waktu Januari 2010-Desember 2012 dengan rincian seperti yang tertera dalam Tabel 2 .

Tabel 1. Jumlah jenazah yang dilaporkan di Bagian Ilmu Kedokteran Forensik dan Medikolegal BLU RSUP Prof. Dr. R.D. Kandou Manado.

\begin{tabular}{cccc}
\hline \multirow{2}{*}{ Bulan } & \multicolumn{3}{c}{ Tahun } \\
\cline { 2 - 4 } & $\mathbf{2 0 1 0}$ & $\mathbf{2 0 1 1}$ & $\mathbf{2 0 1 2}$ \\
\hline Januari & 172 & 177 & 234 \\
Februari & 157 & 164 & 232 \\
Maret & 116 & 393 & 224 \\
April & 159 & 181 & 208 \\
Mei & 195 & 211 & 235 \\
Juni & 167 & 190 & 184 \\
Juli & 153 & 202 & 239 \\
Agustus & 180 & 244 & 254 \\
September & 170 & 207 & 244 \\
Oktober & 156 & 220 & 226 \\
November & 160 & 218 & 216 \\
Desember & 173 & 209 & 226 \\
Total & 1958 & 2616 & 2722 \\
\hline
\end{tabular}

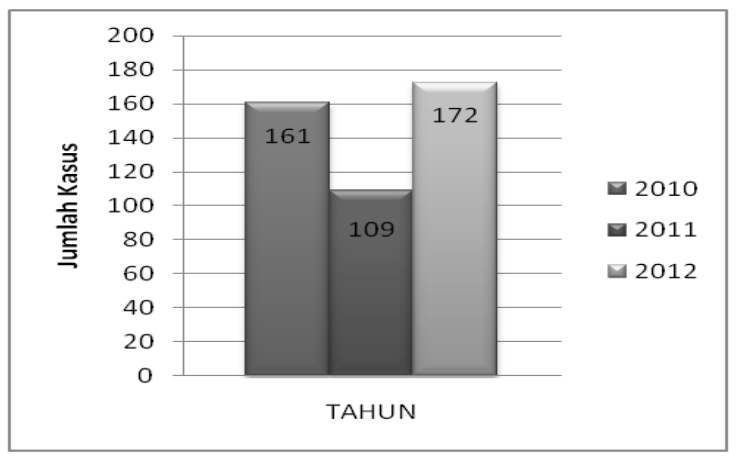

Gambar 1. Grafik jumlah kasus yang dilaporkan di Bagian Ilmu Kedokteran Forensik dan Medikolegal BLU RSUP Prof. Dr. R.D. Kandou Manado. 
Tabel 2. Jumlah Jenazah tanpa identitas yang dilaporkan di Bagian Ilmu Kedokteran Forensik dan Medikolegal BLU RSUP Prof. Dr. R.D. Kandou Manado periode Januari 2010Desember 2012.

\begin{tabular}{ccc}
\hline Tahun & $\begin{array}{c}\text { Jumlah jenazah } \\
\text { tanpa identitas }\end{array}$ & $\%$ \\
\hline 2010 & 6 & $30 \%$ \\
2011 & 5 & $25 \%$ \\
2012 & 9 & $45 \%$ \\
Total & 20 & $100 \%$ \\
\hline
\end{tabular}

Kasus bencana yang dilaporkan di BLU RSUP Prof Dr. R.D Kandou Manado ialah kecelakaan lintas udara jatuhnya helikopter di wilayah perkebunan Kelurahan Danowudu Kecamatan Ranowulu Kota Bitung tahun 2011 (jumlah korban 10 orang) dan bencana longsor di Kota Manado pada tahun 2011 dan 2012 (jumlah korban masing 10 dan dua orang), tetapi prosedur DVI hanya diterapkan pada korban jatuhnya helikopter sedangkan korban kedua bencana lainnya langsung dibawa pulang oleh keluarga.

Pada saat jenazah diminta untuk dilakukan otopsi, pihak kepolisian akan membuat surat yang berisi permintaan otopsi dengan merujuk pada pasal 133, 134 dan 136 KUHAP serta Undang-undang No. 2 tahun 2002 tentang Kepolisian Negara Republik Indonesia. Selain itu, surat tersebut memuat identitas dari jenazah, yaitu: nama, jenis kelamin, umur, kewarganegaraan, agama, pekerjaan, dan alamat. Jika data tersedia, kondisi saat mayat ditemukan beserta tempat ditemukan mayat tersebut juga dicantumkan dalam laporan. Dokter ahli forensik akan melakukan pemeriksaan terhadap mayat tersebut. Proses identifikasi di BLU RSUP Prof. Dr. R.D. Kandou dilakukan oleh dokter ahli Forensik dibantu oleh staf bagian Ilmu Kedokteran Forensik dan Instalasi Pemulasaran Jenazah.

Hasil pemeriksaan jenazah dimasukkan dalam laporan deduksi yang memuat data jenazah seperti nama, alamat, kematian menurut polisi, jenis kelamin, dan pekerjaan. Selain data jenazah, juga dicantumkan waktu pemeriksaan yaitu: hari, tanggal, serta jam dilaksanakan pemeriksaan tersebut. Penanggung jawab, pembantu, pelaksana dan penulis laporan juga dicantumkan setelah data jenazah. Selanjutnya, dituliskan data-data hasil pemeriksaan luar, yaitu berupa keterangan label pada jenazah, bungkus mayat dan apa yang menutupi mayat, catatan-catatan mengenai identifikasi, tanda kematian, patah tulang, dan tanda kekerasan. Bila pemeriksaan dalam (otopsi) dilakukan, hasilnya juga dimasukkan dalam laporan deduksi. Setelah kedua pemeriksaan atau salah satu dari pemeriksaan itu dilakukan, ditarik simpulan yang tertulis di bagian akhir dari laporan tersebut.

Identifikasi personal di BLU RSUP Prof. Dr. R.D. Kandou Manado dilakukan pada semua jenazah, baik yang sudah diketahui identitasnya maupun yang belum. Laporan hasil identifikasi tercakup dalam pemeriksaan luar pada laporan deduksi, yaitu: pakaian dan perhiasan yang dikenakan mayat, benda disamping mayat, jenis kelamin, status gizi, suku bangsa, warna kulit, berat badan, identifikasi khusus, rambut kepala beserta alis, kumis dan janggut, mata kanan dan mata kiri, hidung telinga dan mulut, patah tulang, serta tanda kekerasan yang ditemukan. Hasil pemeriksaan luar akan dicantumkan dalam Visum et Repertum dan ditandatangani oleh dokter yang melakukan pemeriksaan. Pada 10 jenazah yang menjadi korban dari kecelakan lintas udara jatuhnya helikopter di Bitung (2011), proses identifikasi dilakukan sesuai dengan prosedur yang telah dibahas di atas. Semua data hasil identifikasi korban bencana dimasukan dalam laporan deduksi sama seperti perlakuan pada jenazah personal. Selain itu, data hasil identifikasi korban juga dimasukkan dalam formulir post mortem yang memenuhi standar Interpol (Pink form). ${ }^{16}$

Pada penelitian ini, semua metode identifikasi seperti yang telah dijelaskan dalam tinjauan pustaka, dipakai sebagai 
metode dalam mengidentifikasi seluruh jenazah, termasuk jenazah tanpa identitas yang menjadi sampel. Dari 20 jenazah sampel, terdapat 4 janin yang diduga merupakan korban aborsi. Selain itu, terdapat 3 jenazah yang diperiksa dalam bentuk kerangka. Masing-masing jenazah yang sudah dijelaskan di atas dilaporkan pada tahun yang berbeda. Salah satu jenazah dilaporkan ke bagian Ilmu Kedokteran Forensik dan Instalasi Pemulasaran Jenazah, namun batal dilakukan otopsi. Perbandingan jenis kelamin lakilaki dan perempuan ialah $3: 1$. Penelitian retrospektif dari Hanzlick dan Smith $^{20}$ mencatat dari 134 jenazah yang memenuhi kriteria inklusi, mayoritas ialah laki- laki dengan rasio 2,94. Penelitian tersebut dilakukan di Perancis dalam kurun waktu enam tahun dan menggunakan semua metode identifikasi sama seperti penelitian ini. ${ }^{20}$

Terdapat sembilan metode yang digunakan dalam mengidentifikasi jenazah. ${ }^{13}$ Data-data yang diperoleh dapat berupa data medik dan data non-medik. Pada penelitian ini, metode tersebut tersirat dalam laporan deduksi. Laporan hasil identifikasi berupa pakaian dan perhiasan yang dikenakan mayat serta benda yang berada disamping mayat mengacu pada metode identifikasi berdasarkan dokumen dan properti. Metode identifikasi ini menganalisis jenazah berdasarkan pakaian dan perhiasan yang dikenakan, serta dokumen seperti kartu identitas (SIM, KTP, paspor dan lain sebagainya yang memuat identitas jenazah tersebut). Tidak menutup kemungkinan bahwa dokumen ataupun properti yang ditemukan di dekat jenazah bukan milik dari jenazah tersebut, terutama pada kecelakaan massal. Selain itu, metode identifikasi medik berupa jenis kelamin mayat, status gizi, suku bangsa, warna kulit, berat badan, panjang badan, rambut kepala beserta alis, kumis dan janggut, mata kanan dan mata kiri, hidung, telinga dan mulut, patah tulang serta identifikasi khusus (tattoo, tahi lalat/nevus, tindik/piercing, dan disunat atau tidak).

Semua jenazah yang dilaporkan $(100 \%)$ diidentifikasi berdasarkan metode visual, properti dan medik. Hal ini sesuai dengan acuan pustaka yang menyatakan bahwa identitas seseorang dapat dipastikan bila paling sedikit dua dari sembilan metode yang digunakan memberikan hasil positif (tidak meragukan), ${ }^{6,15}$ atau jika memungkinkan, metode visual dilengkapi dengan dua atau tiga metode lainnya. ${ }^{14}$ Smith dan Hanzlick ${ }^{20}$ mendapatkan hasil yang tidak jauh berbeda yaitu metode yang paling menunjang identifikasi ialah visual $(52 \%) .{ }^{20}$ Berbeda halnya dengan studi yang dilakukan Cavard et al. ${ }^{21}$ yang memperoleh hasil bahwa hampir 28\% dari jenazah tanpa identitas yang dilaporkan telah diidentifikasi dengan metode biologi molekuler (DNA).

Sampai penelitian ini selesai dilakukan, tidak ditemukan catatan, surat atau laporan yang menjelaskan bahwa jenazahjenazah telah diambil oleh keluarga atau yang bersangkutan dengan jenazah. Jenazah yang tidak diambil oleh keluarga mungkin disebabkan oleh terbatasnya data ante mortem seperti sidik jari, ciri-ciri fisik dan data gigi. Tidak menutup kemungkinan bahwa jenazah tanpa identitas tidak diambil oleh keluarga disebabkan karena tidak adanya laporan orang hilang sehingga sulit membandingkan antara data ante mortem dan data post mortem.

Pada korban bencana massal, dalam hal ini kecelakaan lintas udara (jatuhnya helicopter) di wilayah perkebunan Kelurahan Danowudu Kecamatan Ranowulu Kota Bitung dengan jumlah korban 10 orang, semua metode identifikasi sudah dilaksanakan. Metode identifikasi yang digunakan pada semua korban bencana tersebut ialah berdasarkan visual, dokumen, dan properti. Jika dibandingkan dengan studi yang dilakukan oleh Biau, antropologi forensik yang memegang peranan penting dalam identifikasi korban di beberapa bencana yang ditangani DVI. ${ }^{21,22}$ Pink Form yang berisi data post mortem diserahkan kepada pihak kepolisian sedangkan laporan deduksi disimpan di Instalasi Pemulasaran Jenazah.

Ditinjau dari jumlah korban yang dapat dikategorikan massal, berbagai acuan pustaka memiliki patokan yang berbeda. 
Popzacharieva dan Rao mengemukakan 10 orang korban sudah dapat dikatakan massal, sedangkan Silver dan Sourion mengatakan bahwa patokan ini akan berbeda-beda, tergantung dari lokasi bencana terkait dengan sumber daya dan fasilitas yang tersedia. Sebagai contoh, jumlah lemari pendingin yang tersedia untuk menyimpan jenazah akan bervariasi dari 4 hingga 400 unit antara satu rumah sakit dengan rumah sakit lainnya. ${ }^{4}$ Pada studi ini digunakan patokan Disaster Victim Identification Guide yang dikeluarkan oleh Interpol yang menyebutkan bahwa jumlah korban tidak ditentukan. Menurut panduan tersebut, bencana dapat berupa bencana tertutup dan bencana terbuka. Bencana tertutup ialah bencana dengan jumlah korban yang sudah pasti dan mudah diidentifikasi atau dikelompokan; sebagai contoh, kecelakaan pesawat dengan daftar penumpang. Bencana terbuka ialah bencana katastropik dengan jumlah para korban yang tidak diketahui dan data-data individual yang tidak jelas. ${ }^{16}$

Kecelakaan lintas udara (jatuhnya helicopter) di wilayah perkebunan Kelurahan Danowudu Kecamatan Ranowulu Kota Bitung ini termasuk dalam bencana tertutup. Jumlah korban yang hanya 10 orang memudahkan untuk membandingkan data-data ante mortem dan post mortem. Hal tersebut sesuai dengan panduan Interpol yang menyatakan bahwa membandingkan data ante mortem dengan data post mortem pada bencana tertutup lebih cepat dilakukan dibandingkan pada bencana terbuka. $^{16}$ Tidak menutup kemungkinan bahwa kedua jenis bencana dapat terjadi bersamaan, sebagai contoh sebuah pesawat yang jatuh di pemukiman warga.

Mengenai label pada jenazah yang diteliti, dari keseluruhan 36 jenazah, hanya satu jenazah yang labelnya masih tersedia. Pada jenazah yang lain data keberadaan labelnya tidak jelas. Penomoran jenazah pada korban bencana massal dilakukan berdasarkan panduan dari Interpol. ${ }^{16}$

\section{SIMPULAN}

Pelaksanaan identifikasi di BLU
RSUP Prof. Dr. R.D. Kandou Manado periode Januari 2010-Desember 2012 menggunakan metode visual, dokumen, properti, dan medik, sedangkan untuk identifikasi korban bencana massal digunakan disaster victim identification dari Interpol. Uraian mengenai metode tersebut tersirat dalam laporan deduksi yang memuat data jenazah, hasil pemeriksaan luar dan dalam, serta simpulan,

\section{SARAN}

Diperlukan penanganan yang optimal terhadap setiap jenazah yang ditemukan baik dari pihak masyarakat, kepolisian, maupun dari tim medik agar memudahkan proses identifikasi dan penyidikan. Untuk itu, sosialisasi terhadap masyarakat oleh pihak kepolisian dan tim medik mengenai undang-undang yang berlaku dan tindakan yang perlu dilakukan bila menemukan mayat perlu digalakan.

\section{UCAPAN TERIMA KASIH}

Ucapan terima kasih ditujukan kepada dr. James Siwu, SH, DFM, DK dan DR. dr. Erwin G. Kristanto, SH, Sp.F selaku penguji Skripsi serta seluruh pihak yang secara langsung ataupun tidak langsung menumbuhkan ide dan gagasan pada penulis.

\section{DAFTAR PUSTAKA}

1. Purnomo NR. Jumlah mayat tanpa identitas meningkat 50 persen. Tribun News [homepage on the Internet]. 2011 [cited 2012 Aug 25]. Available from: http://www.tribunnews.com/2011/01/01 /gawat-jumlah-mayat-tanpa-identitasmeningkat-50-persen.

2. Komisi Kepolisian Indonesia. Aneka Peristiwa: "Lima bulan, 1.191 mayat masuk kamar jenazah RSUD Cianjur" [homepage on the Internet]. 2011 [cited 2012 Aug 18 ]. Available from: http:// www.komisikepolisianindonesia.com/s econdPg.php?cat=aneka\&id=4785

3. Firdaus F. BNPB: 1.598 Bencana alam terjadi di tahun 2011 [homepage on the 
Internet]. 2011 [cited 2012 Aug 25]. Available from: http://news.okezone. com/read/2011/12/30/337/549497/bnpb -1-598-bencana-alam-terjadi-ditahun2011

4. Henky, Savitri O. Identifikasi korban bencana massal: Praktik DVI antara teori dan kenyataan. Indonesian Journal of Legal and Forensic Sciences. 2012;2(1):5-7.

5. Monthly Humanitarian Update. OCHA Indonesia [homepage on the Internet]. Januari 2011. [cited 2012 Sept 8]. Available from: http://www.google. co.id/url?sa=t\&rct=j\&q=\&esrc=s\& sour ce $=$ web $\& c d=1 \& c a d=r j a \& v e d=0 C B 8 Q F$ jAA\&url=http $\% 3 \mathrm{~A} \% 2 \mathrm{~F} \% 2 \mathrm{Fochaonline}$ .un.org\%2FOchaLinkClick.aspx\%3Flin k\%3Docha\%26docId\%3D1178979\&ei =LkuNUKSdMIbNrQfZiYDACQ\&usg =AFQjCNFakz2K_8uTrQ3_X_YYdffi wrfuZQ

6. Budiyanto A, Widiatmaka W, Sudiono $S$, Mun'im WAT, Sidhi, Hertian S, et al. Ilmu Kedokteran Forensik. Jakarta: Bagian Kedokteran Forensik Fakultas Kedokteran Universitas Indonesia; 1997.

7. Ilmu Kedokteran Forensik Universitas Hasanudin. Identifikasi Forensik [homepage on the Internet]. Nodate [cited 2012 Aug 18 ]. Available from: http://med.unhas.ac.id/forensik/index.p hp?option=com_content $\&$ task $=$ view $\& \mathrm{i}$ $\mathrm{d}=14 \&$ Itemid $=1$

8. Rajesh B. Principle of Forensic Medicine and Toxicology [monograph online]. New Delhi: Jaypee Brothers Medical, 2011 [cited 2012 Sept 16]. Available from: http://www.jaypeedigital.com/ BookDetails.aspx?id=9789350254936 $\& s r=1$

9. Idries AM. Penerapan Ilmu Kedokteran Forensik dalam Proses Penyidikan. Jakarta: CV Sagung Seto; 2008.

10. Humas UA. Peran dokter gigi dalam identifikasi korban bencana. Universitas Airlangga [homepage on the Internet]. 2008 [cited 2012 Aug 20]. Available from: http://www. unair.ac.id/berita.unair.php?id=963

11. Kitab Undang - Undang Hukum Acara Pidana. Undang- undang Nomor 8 tahun 1981.

12. Sampurna B, Samsu Z, Siswaja TD.
Peranan Ilmu Forensik dalam Penegakan Hukum, Sebuah Pengantar. Jakarta: Pustaka Dwipar; 2008 .

13. Idries AM. Pedoman Ilmu Kedokteran Forensik (Edisi Pertama). Jakarta: Bina Rupa Aksara; 1997.

14. Cordner S, McKelvie H. Developing standards in international forensic work to identify missing persons [homepage on the Internet]. 2002 [cited 2012 Aug 18]. Available from: http://www. icrc.org/eng/assets/files/other/irrc_848_ cordner.pdf

15. Singh S. Penatalaksanaan identifikasi korban bencana. Majalah Kedokteran Nusantara [serial online]. 2008 [cited 2012 Aug 25];41(4):254-258. Available from: http://repository.usu.ac.id/ bitstream/123456789/18620/1/mkndes2008-41\% 20\%2811\%29.pdf

16. INTERPOL. Disaster victim identification guide [homepage on the Internet]. 2009. [cited 2012 Aug 24]. Available from: www.interpol.int/Media/Files/ INTERPOLExpertise/DVI/

17. Wowiling R. Kriteria Identifikasi Pada Jenazah [Skripsi]. Manado: Fakultas Kedokteran Universitas Sam Ratulangi; 2003.

18. Dawidson I. Case reports and background: Difficulties with identification Sweden. J Forensic Odontostomatol. 2011 Jul 1;29(1):44-50. cited 2012 Aug 15]. Available from: http://www.iofos. eu/Journals/JFOS\%20Jun11/7_CASE\% 20REPORTS\%20AND\%20BACKGR OUND-\%20DIFFICULTIES\%20 WITH\%20IDENTIFICATION.pdf

19. Auerkari E. Recent trends in dental forensics. Indonesian Journal of Legal and Forensic Sciences Jakarta. 2008;1(1):5-12

20. Hanzlick R, Smith GP. Identification of the unidentified deceased: turnaround times, methods, and demographics in Fulton County, Georgia. Am J Forensic Med Pathol. 2006;27(1):79-84. [cited 2012 Aug 18]. Available from: http://www.ncbi.nlm.nih.gov/pubmed/1 6501356.

21. Cavard S, Alvarez JC,De Mazancourt P, Tilotta F, Brousseau $P$, de la Grandmaison GL, et al. Forensic and police identification of "X" bodies. A 6years French experience. Forensic Sci- 
S126 Jurnal Biomedik (JBM), Volume 5, Nomor 1, Suplemen, Maret 2013, hlm. S119-126

ence International. 2011;204(1):139-43.

22. Blau S, Briggs CA. The role of forensic anthropology in disaster victim identification (DVI). Forensic Sci Int. 2011;205(1-3):29-35. 